\title{
Vitamin D Dependent Rickets 2b
}

National Cancer Institute

\section{Source}

National Cancer Institute. Vitamin D Dependent Rickets 2b. NCI Thesaurus. Code C131076.

Rickets caused by a post-receptor defect in the vitamin D signaling pathway producing vitamin $\mathrm{D}$ resistance due to constitutive overexpression of a nuclear ribonucleoprotein that competes with the vitamin $\mathrm{D}$ receptor-retinoid $\mathrm{X}$ receptor dimer binding with DNA vitamin D response elements. This condition has a similar phenotype to vitamin D receptor deficiency rickets including elevated 1,25-dihydroxyvitamin D (calcitriol) concentrations. 